\title{
Florida's Pesticidal Substances Exempt from the Federal Insecticide, Fungicide, and Rodenticide Act (FIFRA-Section 25(b)) ${ }^{1}$
}

\section{Frederick M. Fishel ${ }^{2}$}

Effective in 1996, the Environmental Protection Agency (EPA) exempted products containing 31 pesticidal active ingredients and 160 inert ingredients from FIFRA regulation. The EPA concluded that the exemption of these products would not pose unreasonable risks to public health or the environment.

The federal rule allows individual states, including Florida, whose laws do not allow such exemptions, to continue enforcement of their state provisions. In order to market these types of products in Florida under FIFRA section 25(b), the following conditions must be met:

1. Each product brand name, as well as alternate product brand names, must be registered at an annual fee of $\$ 250$.

\section{The words: "EPA EXEMPTED PRODUCT"} must appear on each Florida application for New or Amended Brand Registration form

(DACS13342).
3. Final printed labels must not bear EPA registration numbers.

4. Under the heading of "Active Ingredients," each product must bear a final printed label identifying the name and percentage by weight of each active ingredient. Under the heading of "Inert Ingredients," each inert ingredient must also be listed by name. The inert ingredients must be shown as one total percentage combined. The combined percentages of active and inert ingredients must equal 100\%.

5. The product must not include any false or misleading labeling statements, including those listed in 40 CFR 156.10(a)(5)(i) through (viii).

6 . The product must not bear claims to either control or mitigate microorganisms that pose a threat to human health, including but not limited to disease transmitting bacteria or viruses, or claims to control insects or rodents carrying specific diseases, including but not limited to ticks that carry Lyme disease.

1. This document is PI-55, one of a series of the Agronomy Department, Florida Cooperative Extension Service, Institute of Food and Agricultural Sciences, University of Florida. Original publication date August 2005. Visit the EDIS Web Site at http://edis.ifas.ufl.edu.

2. Frederick M. Fishel, Associate Professor, Agronomy Department, and Director, Pesticide Information Office; Florida Cooperative Extension Service, Institute of Food and Agricultural Sciences, University of Florida, Gainesville, FL 32611.

The use of trade names in this publication is solely for the purpose of providing specific information. UF/IFAS does not guarantee or warranty the products named, and references to them in this publication does not signify our approval to the exclusion of other products of suitable composition.

The Institute of Food and Agricultural Sciences (IFAS) is an Equal Opportunity Institution authorized to provide research, educational information and other services only to individuals and institutions that function with non-discrimination with respect to race, creed, color, religion, age, disability, sex, sexual orientation, marital status, national origin, political opinions or affiliations. U.S. Department of Agriculture, Cooperative Extension Service, University of Florida, IFAS, Florida A. \& M. University Cooperative Extension Program, and Boards of County Commissioners Cooperating. Larry Arrington, Dean 
7. Product(s) which currently bear EPA registration numbers and are in Florida's trade channels will continue to fall under FIFRA regulation.

\section{Active ingredients exempted by EPA from FIFRA regulation}

1. Castor Oil (U.S.P. or equivalent)

2. Cedar Oil

3. Cinnamon* or Cinnamon Oil*

4. Citric Acid*

5. Citronella and Citronella Oil

6. Cloves* and Clove Oil*

7. Corn Gluten Meal*

8. Corn Oil*

9. Cottonseed Oil*

10. Dried Blood

11. Eugenol

12. Garlic* and Garlic Oil*

13. Geraniol

14. Geranium Oil

15. Lauryl Sulfate

16. Lemon Grass Oil*

17. Linseed Oil

18. Malic Acid*

19. Mint* and Mint Oil*

20. Peppermint* and Peppermint Oil*

21. 2-Phenethyl Propionate (2-phenylethyl propionate)

22. Potassium Sorbate

23. Putrescent Whole Egg Solids
24. Rosemary* and Rosemary Oil*

25. Sesame* (includes ground sesame plant stalks) and Sesame Oil*

26. Sodium Chloride (common salt)*

27. Sodium Lauryl Sulfate

28. Soybean Oil

29. Thyme* and Thyme Oil*

30. White Pepper*

31. Zinc Metal Strips (consisting of zinc metal and impurities)

* These active ingredients are exempt for use on all food commodities from the requirement of a tolerance on all raw agricultural commodities at 40 CFR 180.1164(d). 